EESTI NSV TEADUSTE AKADEEMIA TOIMETISED. 21. KÖIDE

KEEMIA * GEOLOOGIA. 1972, NR. 2

ИЗВЕСТИЯ АКАДЕМИИ НАУК ЭСТОНСКОИ ССР. ТОМ 21

ХИМИЯ * ГЕОЛОГИЯ. 1э72, № 2

удК 66.092.3:547.292-295'1-6:543.544

ЕВГЕНИЯ БОНДАРЬ, Р. ВЕСКИ, А. ФОМИНА

\title{
СОСТАВ МОНОКАРБОНОВЫХ КИСЛОТ, СОПУТСТВУЮЩИХ ПРОИЗВОДСТВУ ДИКАРБОНОВЫХ КИСЛОТ ИЗ КЕРОГЕНА КУКЕРСИТА
}

В Институте химии с участием Опытно-технической базы АН ЭССР разработана схема промышленного производства насыщенных дикарбоновых кислот из концентрата керогена кукерсита [ $\left.{ }^{1}\right]$. Из ранее проведенных исследований природы керогена кукерсита известно, что при его окислении различными окислителями наряду с насыщенными дикарбоновыми кислотами образуются монокарбоновые кислоты максимально около $5 \%$ на кероген по весу $\left.{ }^{2}\right]$. Результаты исследований состава монокарбоновых кислот, полученных при окисленин перманганатом калия в щелочной среде, методом колоночной хроматографии на силикагеле показали, что они представляют собой жирные кислоты нормального строения от уксусной до каприловой включительно $\left[{ }^{2}\right]$. В продуктах окисления азотной кислотой $(d=1,51)$ были идентифицированы (тем же способом) только уксусная, пропионовая и масляная кислоты [3].

Целью данных исследований было выявить качественный и количественный состав монокарбоновых кислот, образующих при окислении концентрата керогена кукерсита комбинированным окислителем азотной кислотой и кислородом воздуха.

Монокарбоновые кислоты распределяются в конденсатах узла окисления и узла регенерации азотной кислоты. Конденсаты представляют собой водный раствор азотной кислоты с некоторым содержанием органических кислот, в том числе монокарбоновых.

С целью выделения этих кислот конденсаты нейтрализовались твердым едким кали до слабощелочной реакции. Нейтрализованные растворы упаривались и высушивались. Кислоты экстрагировались из смеси их калиевых солей и нитрата калия серным эфиром, подкисленным серной кислотой. Әфирные экстракты после сушкн безводным сернокислым натрием метилировались диазометаном.

Метилированные эфирные экстракты анализировались методом газожидкостной хроматографии на хроматографе УХ-2 Выруского завода газоанализаторов с пламенно-ионизационным детектором.

Так как органическая кислотность конденсатов, определяемая потенциометрическим титрованием, обусловлена присутствием в них не только монокарбоновых кислот, для однозначной идентификации последних метилированные эфирные экстракты были анализированы на двух колонках с различными жидкими фазами: силиконовым каучуком, кондиционированным при $300^{\circ} \mathrm{C}$ в вакууме, и динонилфталатом на хромосорбе $W$. На рис. 1 приведен график зависимости логарифма относительного удер- 


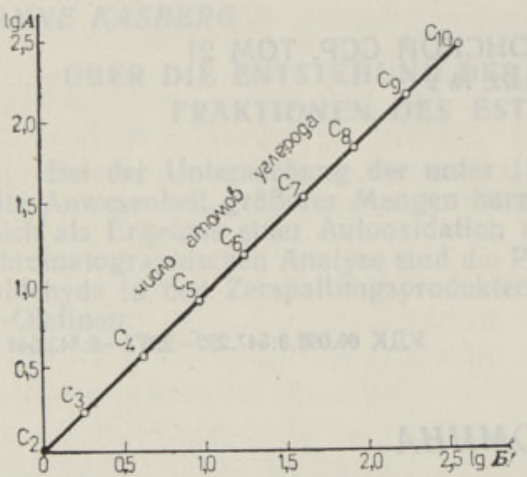

Рис. 1. Зависимость между лога рифмом относительного удерживае. мого объема на динонилфталате $(\lg A)$ и логарифмом относительного удерживаемого объема на силиконовом каучуке (ig $\bar{b}$ ) для метиловых эфиров насыщенных жирнын кислот $\mathrm{C}_{2}-\mathrm{C}_{10}$.

живаемого об́ ьема на силиконовом каучуке от логарифма относительного удерживаемого объема на динонилфталате для метиловых эфиров монокарбоновых кислот $\mathrm{C}_{2}-\mathrm{C}_{10}$, с помощью которого эти кислоты были идентифицированы в исследуемых смесях.

Количественный анализ был проведен на колонке длиной $1,25 \mu$ и диаметром 6 мм, жидкая фаза - 10\% динонилфталата с добавкой $10 \%$ стеариновой кислоты на хромосорбе $W$ фракции $0,2-$ 0,25 м.. Скорость газа-носителя аргона $50 \mathrm{M} /$ мuн, температура $100^{\circ}$.

Для расчета хроматограмм в качестве внутреннего стандарта был выбран метиловый эфир бензойной кислоты, пик которого выходит между метиловыми эфирами энантовой $\left(\mathrm{C}_{7}\right)$ и каприловой $\left(\mathrm{C}_{\curlyvee}\right)$ кислот. Для определения поправочных коэффициентов были использованы калибровочные смеси метиловых эфиров монокарбоновых кислот $\mathrm{C}_{2}-\mathrm{C}_{10}$ и бензойной кислоты. На рис. 2 приведена хроматограмма смеси метиловых эфиров жирных кислот, выделенных из одного из конденсатов.

Количество отдельных монокарбоновых кислот в процентах $\left(A_{n}\right)$ на кероген рассчитывали по формуле

$$
A_{n}=\frac{G \cdot a_{n} \cdot M_{n} \cdot V}{1000 \cdot M_{2} \cdot G_{k}}
$$

где $G$ - общее количество органических кислот в пересчете на уксусную кислоту в конденсатах, определяемое потенциометрическим титрованием исходного конденсата, г/ $\Omega$;

$a_{n}$ - содержание монокарбоновой кислоты $C_{n}$ в экстракте органических кислот, выделенных из соответствующего конденсата, \% (определялось газожидкостной хроматографией);

$M_{n}$ - молекулярный вес монокарбоновой кислоты $C_{n}$;

$\mathrm{M}_{2}$ - молекулярный вес уксусной кислоты;

$V$ - количество конденсата, $\Omega$;

$G_{h}$ - количество керогена кукерсита, взятого на окисление, $\kappa 2$.

Результаты расчета приводятся в табл. 1.

Кроме водных конденсатов узла окисления и узла регенерации азотной кислоты, на содержание монокарбоновых кислот был исследован очень небольшой маслянистый слой из сборника конденсата узла окисления, распределяющийся по поверхности водного конденсата. После метилирования диазометаном маслянистый слой был качественно анализирован на хроматографе $\mathrm{YX}-2$ с катарометром на пслярной (полиэтиленгликольадипинат) и неполярной (апиезон $L^{R}$ ) жндких фазах, что позволило однозначно идентифицировать содержащиеся в этом слое монокарбоновые кислоты. На рис. 3 приведена хроматограмма маслянистого слоя на колонке длиной 2 и и диаметром 6 мм с $10 \%$ полиэтиленгликольадипината на рысорбе, при $185^{\circ}$ и скорости газа-носителя гелия $120 \mathrm{M \Omega} / \mathrm{мuн}$. 


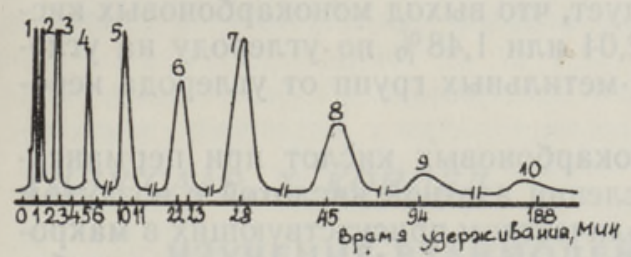

Рис. 2. Разделение смеси метиловых эфиров жирных кислот, содержащихся в конденсате узла регенерации азотной кислолы, на динонилфталате: 1 - уксусной, 2 - пропионовой, 3 - масляной, 4 - валериановой, 5 капроновой, 6 - энантовой, 7 - бензойной (внутренний стандарт), 8- каприловой, 9 - пеларгоновой, 10 - каприновой.

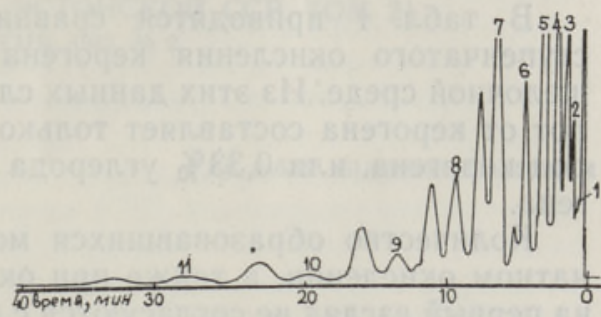

Рис. 3. Разделение метиловых эфиров монокарбоновых кислот, содержащихся в маслянистом слое, на полиэтиленгликольадипинате:

1 - валериановой, 2 - капроновой, 3 энантовой, 4 - каприловой, 5 - пеларгоновой, 6 - каприновой, 7 - ундекановой, 8 - лаурнновой, 9 - тридекановой, 10 - миристиновой, 11 - пентадекановой.

Из данных табл. 1 и рис. 2 и 3 следует, что в продуктах окисления керогена кукерсита удалось дополнительно к определенным ранее монокарбоновым кислотам $\mathrm{C}_{2}-\mathrm{C}_{8}$ идентифицировать пеларгоновую, каприновую, ундекановую, лауриновую, тридекановую, миристиновую и пентадекановую кислоты $\left(\mathrm{C}_{9}-\mathrm{C}_{15}\right)$.

Источником образования монокарбоновых кіслот при окислительной деструкции могут быть алифатические прямоцепочные боковые радикалы. К настоящему времени общим мнением является то, что одним из основных исходных компонентов материнского вещества керогена кукерсита являются непредельные, а также предельные, жирные кислоты $[2,4,5]$.

Алифатическая природа значительной части керогена (около $70 \%$ ) была доказана прямым выделением насыщенных дикарбоновых кислот при окисленни керогена кукерсита [ $\left.{ }^{2}\right]$. На основе данных анализа смолы полукоксования сланца кукерсита был сделан вывод о том, что примерно $40 \%$ углерода керогена находится в прямолинейных цепях, содержащих преимущественно $12-16$ атомов углерода [6]. Кроме того, из работы [7] известно, что кероген кукерсита содержит в С-метильных группах 3,3\% углерода от исходного в керогене, что согласуется с данными [6].

Образование монокарбоновых кислот на кероген кукерсита, \%

\begin{tabular}{|c|c|c|c|c|}
\hline \multirow[b]{2}{*}{ Кислота } & \multirow[b]{2}{*}{$\begin{array}{c}\text { Условное } \\
\text { обозначение }\end{array}$} & \multicolumn{2}{|c|}{ Окисление } & \multirow{2}{*}{$\begin{array}{c}\text { При окислении } \\
\text { пермангана- } \\
\text { том калия * }\end{array}$} \\
\hline & & $\begin{array}{c}\text { с применением } \\
\text { регенериро- } \\
\text { ванной азот- } \\
\text { ной кислоты }\end{array}$ & $\begin{array}{c}\text { с применением } \\
\text { свежей азот. } \\
\text { ной кислоты }\end{array}$ & \\
\hline
\end{tabular}

\begin{tabular}{lllll} 
Уксусная & $\mathrm{C}_{2}$ & 0,67 & 0,71 & 0,23 \\
Пропионовая & $\mathrm{C}_{3}$ & 0,30 & 0,01 & 0,32 \\
Масляная & $\mathrm{C}_{4}$ & 2,15 & 0,19 & 0,39 \\
Валериановая & $\mathrm{C}_{5}$ & 0,54 & 0,17 & 0,41 \\
Капроновая & $\mathrm{C}_{6}$ & 0,16 & 0,13 & 031 \\
Энантовая & $\mathrm{C}_{7}$ & 0,47 & 0,06 & 0,23 \\
Каприловая & $\mathrm{C}_{8}$ & 0,24 & 0,24 & 0,15 \\
Пеларгоновая & $\mathrm{C}_{9}$ & 0,22 & 0,03 & - \\
Каприновая & $\mathrm{C}_{10}$ & 0.16 & - & - \\
\hline \multicolumn{1}{c}{ Всего } & & 4,91 & 1,54 & 2,04 \\
\hline
\end{tabular}

* Рассчитано на основе экспериментальных данных (см. габл. $\left.35\left[{ }^{2}\right]\right)$. 
В табл. 1 приводятся сравнительные экспериментальные данные ступенчатого окисления керогена кукерсита перманганатом калия в щелочной среде. Из этих данных следует, что выход монокарбоновых кислот от керогена составляет только 2,04 или $1,48 \%$ по углероду на углерод керогена, или $0,33 \%$ углерода С-метильных групп от углерода керогена.

Количество образовавшихся монокарбоновых кислот при перманга . натном окислении, а также при окислении азотной кислотой с воздухом на первый взгляд не согласуются с количеством присутствующих в макромолекуле керогена алифатических открытых цепей, указанных в работе [7]. Но, по всей вероятностн, это кажущееся противоречие объясняется тем, что подавляющее количество образовавшихся монокарбоновых кислот в условиях опыта окисляется дальше до дикарбоновых кислот.

Идентификация в продуктах окисления керогена кукерсита азотной кислотой и воздухом жирных монокарбоновых кислот нормального строения $\mathrm{C}_{9}-\mathrm{C}_{15}$ является прямым подтверждением наличия в макромолекулярном веществе керогена кукерсита длинных боковых цепей нормального строения.

\section{Л И Т Е Р А Т У Р А}

1. Фомина А. С., Вески Р. Э., Дегтерева З. А., Побуль Л. Я., Таль де р Э. С., М янни к А. О., Пя рн А. В., Разработка и использование горючих сланцев. Труды I симпозиума Организации Объединенных Наций по разработке и использованию запасов горючих сланцев (Таллин, 1969). Таллин, 1970, с. 217.

2. Фомина А. С., Побуль Л. Я., Д егтерев а З. Я., Природа керогена прибалтийского горючего сланца-кукерсита и его химические сырьевые качества. Таллин, 1965.

3. Ф омин а А. С., Д егте ре в а 3. А., Изв. АН ЭССР, сер. физ.-матем. и техн. наук, 5, $276(1956)$.

4. Д о б р я н с к и й А. Ф., В сб.: Низкотемпературные каталитические превращения углеводородов. Изд. ЛГУ, 1962, с. 12.

5. Р а уд с еп п Х. Т., В сб.: Генезис твердых горючих ископаемых. М., 1959, с. 57.

6. Клесмент И. Р., Химия твердого топлива (в печати).

7. У ров К. Э., Ли твиновская В. И., С толер Э И., Тр. Таллинск, пюлитехн. ин-та, сер. А, № 270, 137 (1969).

Ннститут химии

Академии наук Эстонской ССР
Поступила в редакцию 22/VII 1971

JEVGENIA BONDAR, R. VESKI, A. FOMINA

\section{DIKARBOKSUOLHAPETE TOOTMISEL KUKERSIIDIKEROGEENIST KORVALPRODUKTIDENA TEKKIVATE MONOKARBOKSUULHAPETE KOOSTIS}

Kukersiidikerogeeni oksüdeerimisel lämmastikhappe ja õhuhapnikuga tekib dikarboksüülhapete kõrval vähesel määral ka monokarboksüülhappeid. Gaasikromatograafi yX-2 abil määrati niisuguste kõrvalproduktidena äädik-, propioon-, või-, palderjan-, kaproon-, enant-, kaprüül-, pelargoon-, kapriin-, undekaan-, lauriin-, tridekaan-, müristiin- ja pentadekaanhape, neist seitse viimast tehti oksüdatsiooniproduktides kindlaks esmakordselt.

\section{EUGENIA BONDAR, R. VESKI, A. FOMINA}

\section{THE COMPOSITION OF MONOCARBON ACIDS FORMED AT THE PRODUCTION OF DICARBOXYLIC ACIDS FROM KUKERSITE KEROGEN}

At the production of dicarboxylic acids by the oxidation of kukersite kerogen with nitric acid and air oxygen, minor quantities of fatty acids are also formed.

Acetic, propionic, butyric, valeric, capronic, enantic, caprylic, pelargonic, capric, undecoic, lauric, tridecanoic, myristic, and pentadecylic acids have been identified in the oxidation products by chromatographic analysis, the seven latter for the first time. For this purpose, the gas-chromatograph $\mathrm{yX}-2$ was used. 